\title{
GENERATION MEAN ANALYSIS OF EARLINESS AND CHOCOLATE SPOT DISEASE RESISTANCE AND QUALITATIVE VARIATION IN THE STORAGE PROTEINS OF THREE Vicia faba L. CROSSES \\ Abo Mostafa, R.A.I.*; W. M. El-Rodeny * and Aziza M. Hassanein** \\ * Food Legumes Res. Sec. Field Crops Res. Inst., Agric. Res., Center (ARC). \\ ** Seed Technology Research Dep., Field Crops Res. Inst., Agric. Res., Center (ARC), Egypt
}

\begin{abstract}
Production of grain legumes is limiting by the usual array of pathogenic that affect plants. The present study was conducted during 2005/06, 2006/07 and 2007/08 seasons at Sakha Agricultural Research Station (SARS). A quantitative analysis were done by using six generations mating design between five faba bean parental genotypes namely; Rena Mora, Sakha1, Giza 3, Sakha 2 and T.W to produces three crosses namely; Rena Mora x Sakha1, Giza 3 x Rena Mora and Sakha 2 x T.W. The parental genotypes could be arranged in to three groups. The first group included; Rena Mora, Sakha 1 and Sakha 2 where it is considered as the most resistant group to chocolate spot and high yielding ability. The second group included Giza 3 which is moderate resistant to chocolate spot and the third group include T.W as susceptible genotypes with low yielding potentiality. The data revealed that, the parental genotypes and their crosses had the highest value of variation according to relation to chocolate spot reaction and maturity date. Heterosis over mid and better parent for all traits were highly significant except chocolate spot reaction in the two crosses; (Rena Mora $x$ Sakha1) and (Sakha $2 \times$ T.W.) relative to mid parents. And also, for no. of pods/plant in the cross; (Rena Mora $\times$ Sakha1) relative to better parent. Potence ratios were exceeded unity for most traits indicating over dominance. On the other hand, the values of this parameter were less than unity in the cross; (Sakha $2 \times$ T.W.) for maturity date, no. of branches/plant, seed yield/plant(g), 100 seed weight and chocolate spot reaction, indicating partial dominance. The inbreeding depression estimates were highly positively significant for no. of pods/plant, no. of seeds/plant and seed yield/ plant(g) in the two crosses (Rena Mora x Sakha1) and (Giza $3 \times$ Rena Mora). The additive type (a) was significant positive or negative values in all of crosses for all traits except in the cross; (Rena Mora $x$ Sakha 1). For dominance effect (d) it was and higher in magnitude than that of additive type of gene effects. The additive $\mathrm{x}$ additive gene effect was highly positive significant in most crosses except in the cross; (Rena Mora x Sakha 1) for no. of branches/plant. However, highly significant positive epistatic gene action (ad) was observed in the first cross; (Rena Mora $x$ Sakha 1) for no. of branches/plant, no. of pods/plant, no. of seeds/plant and chocolate spot reaction. Heritability values in broad-sense were generally higher than the corresponding values in narrow-sense in all crosses for all traits. The additive genes seems to play an important role of the inheritance of maturity date, no. of branches/plant, no. of pods/plant and chocolate spot reaction in the cross; Rena Mora x Sakha1, where the differences between broad and narrow-sense heritability were closest. The indirect selection in the progeny of the crosses; Rena Mora $x$ Sakha 1 and Giza $3 \times$ Rena Mora and direct selection in the progeny of the cross (Sakha $2 \times$ T.W.) would be fruitful due to the high values of narrow-sense heritability and the prediction genetic advance in these cases. The fingerprinted by SDS-PAGE of water-
\end{abstract}




\section{Abo Mostafa, R.A.I. et al.}

soluble proteins were performed in two crosses. The results reveled that bands number 2, with MWs 192KDa. was found only in cross Giza 3 x Rena Mora and also exist in the parental genotypes Giza 3 and could be considered as specific bands (positive markers) for these cross. These results support the validity of seed protein electrophoresis as a powerful tool for cultivar identification, clarifying taxonomic and evolutionary problems and studying genetic diversity of Vicia faba.

Keywords: Vicia faba, heritability, genetic components, seed proteins electrophoresis

\section{INTRODUCTION}

Faba bean crop has attracted the attention of most plant breeders to improve its yield because the importance of the crop for both human and animal nutrition. chocolate spot, due to the fungus Botrytis fabae, is the most destructive leaf disease of faba bean crop in the world. The losses as a result to foliage diseases infection were estimated to be more than $55 \%$ for susceptible cultivar Rebaya 40 which was left for natural infection at Sakha (Mohamed et al. 1980). Damages caused by foliar pathogens affecting supply and translocation of photosynthates are prime importance. Although chemical control may provide partial protection, it is costly for small farmers, reduces the crops profitability, and is harmful to the environment. Therefore, selecting resistant varieties is an efficient option to control the disease and an appropriate strategy to promote the development of sustainable agriculture. In this regard, formal plant breeding programs have mainly focused on the production of input responsive and broadly adapted cultivars that show high performance over a wide range of environments. Therefore, cultivars offered by formal plant breeding have to be "distinctive, uniform and stable. Reviewed the contributions of plant breeding facing these problems showing resistance to chocolate spot (Botrytis fabae) has been identified in ICARDA lines coming from Ecuador (Bond et al., 1994). The improvement of seed yield and yield stability are the primary objectives of most faba bean breeding program, in Egypt; The challenge in breeding faba bean resides mainly in its reproductive system being partial allogamous. The genetic variability within open-pollinated faba bean varieties and the proportion of heterosis occurring under partial allogamy was studied by Ebmeyer and Stelling (1994). Their results showed that $70 \%$ of heterosis for grain yield was achieved for crosses between inbred lines of different varieties and that heterosis could be utilized in open pollination. Characterization of the genetic variation in the available germplasm is important for further improvement of crop yield and to impart resistance to biotic and abiotic stresses (Kour and Singh, 2004). The separation of seed protein components in polyacrylamide gels are mostly informative at the species and infra-specific levels (Nei et al., 1979 and Cooke, 1984). Seed protein data have, therefore been applied to study genetic diversity at interspecific levels (Signor et al., 2005; Mustafa et al., 2006; Sammour et al., 2007) and also for cultivar identification (Sammour, 1988, 1990a, 1992; and Thanh et al., 2006). Electrophoretic techniques offer an exceptional opportunity to study the substructure differences in protein among different genotypes. Nevertheless, SDS-PAGE was used to differentiate between $V$. faba cultivars (Stegemann 1983) and to identify 
inbred lines (Gates and Boulter 1979). On the other hand, several researchers have found a greater amount of variation in seed storage protein fractions, legumin and vicilin (Gatehouse et al., 1980). The aim of the present study was to study of genetic diversity and inheritance of earliness, chocolate spot disease resistance, and seed yield and its components of faba bean (Vicia faba L.) crosses and their parents through the six generations mean analysis.

\section{MATERIALS AND METHODS}

Field Experiments: The present study was carried out during 2005/06, 2006/07 and 2007/08 seasons at Sakha Agricultural Research Station (SARS). In the 2005/06 season five parents of faba bean genotypes namely; Rena Mora, Sakha1, Giza 3, Sakha 2 and T.W were grown and crossed under free insect cage at SARS to produce $F_{1}$ seeds. Three crosses were produced namely; Cross I (Rena Mora x Sakha1), cross II (Giza 3 x Rena Mora) and cross III (Sakha $2 \times$ T.W.). The origin, Pedigree, disease reaction and other agronomic characters of these materials are presented in Table (1). In the 2006/07, $F_{1}$ 's and their parents for each cross plants were sown under wirecages, $F_{1}$ plants were selfed and backcrossed to each parent to obtain the $\mathrm{F}_{2}, \mathrm{Bc}_{1}$ and $\mathrm{Bc}_{2}$. In 2007/08 the six generations of all crosses were tested under natural infection at early sowing dates in the November $1^{\text {st. }}$ (Early date). The experiment was arranged in a randomized complete block design with three replications. The plants were grown in ridges of two meters long and $60 \mathrm{~cm}$. wide. Hills were spaced $20 \mathrm{~cm}$. apart with one seed per hill. Plots varied in size; 15 rows for $F_{2}$, three rows for $\mathrm{Bc}_{1}$ and $\mathrm{Bc}_{2}$ and three rows for $\mathrm{P}_{1}, \mathrm{P}_{2}$ and $\mathrm{F}_{1}$. All cultural practices were done as usual with ordinary faba bean culture. Data were taken on plants of the six populations in each cross for the following characters:

Table 1: The Pedigree, diseases reaction and agronomic characters of five parental faba bean varieties used in the present study.

\begin{tabular}{|c|c|c|c|c|c|c|}
\hline \multirow{2}{*}{ No. } & \multirow[t]{2}{*}{ Parents } & \multirow[t]{2}{*}{ Pedigree } & \multirow{2}{*}{$\begin{array}{l}\text { Disease } \\
\text { reaction }\end{array}$} & \multirow{2}{*}{$\begin{array}{c}\text { Earliness } \\
\text { of }\end{array}$} & \multicolumn{2}{|c|}{ Agronomic traits } \\
\hline & & & & & Seed coat color & $\begin{array}{l}\text { Seed } \\
\text { size }\end{array}$ \\
\hline 1 & Rena Mora (R.M) & $\begin{array}{l}\text { Introduction from } \\
\text { Spain }\end{array}$ & $\mathrm{R}$ & Medium & Violet $\left(\right.$ B. $\left.H^{*}\right)$ & Large \\
\hline 2 & Sakha1 & $\begin{array}{l}\text { Giza 716 x } \\
620 / 283 / 85\end{array}$ & $\mathrm{R}$ & Very Early & Light brown (B.H) & Medium \\
\hline 3 & Giza 3 & $\begin{array}{c}461 / 845 / 83 \times 561 \\
/ 207685 \\
\end{array}$ & $\mathrm{MR}$ & Medium & Light brown (B.H) & Medium \\
\hline 4 & Sakha 2 & X. 952/1265 & H.R & Late & $\begin{array}{l}\text { Light brown } \\
\left(\text { W. } H^{* *}\right)\end{array}$ & Large \\
\hline 5 & T.W. & $\begin{array}{l}\text { Introduction from } \\
\text { Sudan }\end{array}$ & H.S & Early & White (W.H) & Small \\
\hline
\end{tabular}


maturity date, no. of branches/plant, no. of pods/plant, no. of seeds/plant, weight of 100 seeds, seed yield/plant and chocolate spot reaction under the natural infection. The resistance to chocolate spot caused by (Botrytis fabae) diseases were determined as in Table (2) with the adjustment of grading system from 0 to 9 for the increasing lesion percentage of leaf, flower and stem area covered by lesions, according to the scale of Bernier et al. (1984).

Table 2: Rating scale for chocolate spot (Botrytis fabae).

\begin{tabular}{|l|l|}
\hline Rate & Description \\
\hline 1 & No disease symptom, or very small specks (Highly resistant) \\
\hline 3 & Few small discrete lesions (Resistant) \\
\hline 5 & Some coalesced lesions with some defoliation (Moderately resistant) \\
\hline 7 & Large coalesced sporulating lesions, $50 \%$ defoliation, some dead plants (Susceptible) \\
\hline 9 & $\begin{array}{l}\text { Extensive lesions on leaves, stems and pods: sever defoliation heavy sporulation: } \\
\text { stem girdling: blackening and death of more than } 80 \% \text { of plant ( Highly susceptible) }\end{array}$ \\
\hline
\end{tabular}

Statistical analysis: All the genetic analysis was done using means and the variance for $\mathrm{P}_{1}, \mathrm{P}_{2}, \mathrm{~F}_{1}, \mathrm{Bc}_{1}, \mathrm{Bc}_{2}$ and $\mathrm{F}_{2}$ populations. A.B.C and $\mathrm{D}$ scaling test of Mather (1949) were used to test the adequacy of the additive-dominance model and also, to study the non-allelic interaction. The Gamble (1962) procedure's was used to estimate the genetic variance of generation mean and gene action (type of gene effects). The variance of each of the genetic variance components was estimated as linear function of the variance of the mean squares. The variance of a mean square was calculated as a given by (Anderson and Bancroft (1952) and estimates the heritability. Heterosis and percentage of inbreeding depression (I.D \%) were measured according (Mather and Jinks, 1971). The nature and type of dominance were determined by means of potence ratio method $(P)$ which can be defined according (Smith, 1952). Expected values of genetic advance (GS) was calculated according to Johanson et al. (1955) using the selection differential (K) equal 2.06 for $5 \%$ selection intensity. Prediction genetic advance as percent of the $F_{2}$ mean (GS \%) was calculated as given by Miller et al, (1958).

Biochemical identification: SDS-Polyacrylamide Gel Electrophoresis (SDSPAGE) total seed protein was extracted from the five Vicia faba genotypes. These protein extractions were analyzed using SDS-PAGE according to the method of Laemmli (1970). A dendrogram was constructed through the complete linkage-joining rule. Nei's similarity index (Nei and Li, 1979) was calculated also among the studied genotypes where:

Nei's similarity index $=$ The No. of bands in common among all genotypes

Total No. of bands

\section{RESULTS AND DISCUSSION}

The data in Table (3) showed the mean performance, variance, mean variance and coefficient of variation for the six populations of the crosses among different traits. Significantly differences were observed among most 
genotypes for measured traits. The parental genotypes could be arranged into three groups. The first group, included the genotypes of Rena Mora, Sakha 1 and Sakha 2, which are considered to be the most resistant group to chocolate spot with high yielding ability where the yield values were: 74.43 , 65.11 and 71.02 , respectively in addition it is had less rating scale value of chocolate spot reaction; 3.17, 3.33 and 3.00, respectively. The second group included Giza 3 which is moderate resistant chocolate spot (5.57). The third group include; T.W as susceptible genotypes (7) accompanied with low yielding ability (54.38). The data in Fig. $1 \mathrm{~A}$, showed the relation between six populations of the three crosses and their reactions to chocolate spot $(A)$ and maturity date (B). The low infected genotypes are generally accompanied by relatively better host reaction, and higher percentage of fruiting plants and higher seed yield. Fig. 1B, showed that the genotypes differed in the values of maturity date and can classified these genotypes into three groups; the first one included the very earliness genotypes T.W. and Sakha 1 with 144.00 and 144.83days from the sowing date to full maturity phase, the second group included the moderate value in earliness 155.43 days for Giza 3 and 155.17 days for Rena Mora, and the third group included lateness genotype, Sakha 2 with 165 days. The difference between the studied crosses with respect to chocolate spot resistance and earliness traits could be observed from the fingers $1 \mathrm{~A}$ and $1 \mathrm{~B}$, respectively. Also, significant genetic variance were detected for all traits in the three crosses and therefore, genetic parameters were detected as reported by Khalil et al. (1993b) and Attia et al. (2006). The data showed also that $F_{1}$ 's were intermediate between their parental genotypes for the time required for maturity, while, $F_{2}$ 's later than their $\mathrm{F}_{1}$ 's in all crosses. While back cross were closer to back crosses parent. The $F_{1}$ 's means for the yield and its components traits were higher than those three parents, except no. of branches/plant for the combinations of Sakha2 $x$ T.W. and 100 seed weight for all crosses, this was reflected in the appearance of positive highly significant heterosis for theses characters (Table 4). 
Abo Mostafa, R.A.l. et al.

T3

798 
J. Agric. Sci. Mansoura Univ., 34 (2), February, 2009

t3

799 
Abo Mostafa, R.A.l. et al.

$\mathrm{T} 4$

800 
The data presented in Table 4 indicated that heterosis over mid and better parent for all traits were highly in negative or positive direction, except chocolate spot reaction in two crosses (Rena Mora $x$ Sakha1) and (Sakha $2 \mathrm{x}$ T.W.) over mid parents, and also, in no. of pods/plant for cross (Rena Mora $x$ Sakha1) over the better parent. The inbreeding depression estimates were high significant in positive direction for no. of pods/plant, no. of seeds/plant and seed yield/ plant $(\mathrm{g})$ for the two crosses (Rena Mora $\times$ Sakha1) and (Giza $3 \times$ Rena Mora), and also for no. of branches in the crosses (Giza $3 \times$ Rena Mora) and (Sakha $2 \times$ T.W.). However, it was negative significant for maturity date in the cross; (Rena Mora x Sakha1). Potence ratios were exceeding unity for most traits concerning yield and its components, indicating over dominance. On the other hand, the values of this parameter were less than unity but not equal zero in cross; (Sakha $2 \times$ T.W.) for maturity date and chocolate spot reaction, indicating partial dominance. The presence of heterosis over better parent with respect to the cross; (Rena Mora x Sakha1) for maturity date and chocolate spot reaction in negative direction and no. of branches/plant, no. of seeds/plant and seed yield/plant in positive direction, which would indicate that the progeny of this cross could be used in breeding program for maturity, chocolate spot reaction and high yielding ability. Moreover; the progeny of the crosses; (Rena Mora x Sakha1) and (Giza $3 \times$ RenaMora) could be used in breeding program for high yielding potentiality due to the presence of useful heterosis as the results indicated. Inbreeding depression ranged from $27.8 \%$ to $61.1 \%$ in the cross; (Rena Mora $\times$ Sakha1) and from $34.44 \%$ to $56.84 \%$ in the cross; Giza $3 \times$ Rena Mora for no. of branches/plant, no. of pods/plant, no. of seeds/plant and seed yield/plant. However it might be concluded that one generation of selfing has been sufficient to bring about an inbreeding depression that could negate most of heterosis obtained from crossing for these traits. These results are in harmony with those reported by Abdalla (1977), El-Refaey and Radi (1991), Hendawy et al (1994), El- Hosary et al. 1997; El-Hady et al. (1998), Toker (2004) and Attia et al. (2006).

The estimated values of different scaling test according to Mather (1949) and Hayman and Mather (1955), as well as six-parameters describing the nature of gene action and their test of significance according to Gamble (1962), for all studied traits are presented in Table(5). (A) and (B) and tests provides evidence of all types of non-allelic gene interaction. The significance of $C$ scale suggests (dd) type of epistasis. The significant $D$ scale reveals (aa) gene interaction, significance of C and D scales indicates (aa) and (dd) type of gene interaction. The test of adequacy of scales is important because in most cases the estimation of additive and dominance components of the variance are made assuming absence of gene interaction. The values of $A$, $B, C$, and D should significantly differ than zero within the Limits of their stander error. However, the results (Table 5) indicated that the values of scaling tests were significantly differ than zero for all studied traits in all crosses, except maturity date of the second cross, indicating that the additive-dominance model is inadequate to interpret the gene effects (Mather, 1949). 
Abo Mostafa, R.A.l. et al.

T5

802 
J. Agric. Sci. Mansoura Univ., 34 (2), February, 2009

t5

803 
The estimated mean effect parameter $(m)$, which reflects the contribution due to the over-all mean plus the locus effects and the interaction of the fixed loci was found to be highly significant for all traits of the three crosses.

The additive type (a) was significant in positive or negative direction in all crosses for all traits, except in the cross (Rena Mora $x$ Sakha 1) for maturity date, and also, for dominance effect (d) where its highly in magnitude than that of additive type. The additive $x$ additive gene effect was highly positive significant in most crosses; except in the first cross; (Rena Mora $x$ Sakha 1) for no. of branches/plant. However, significant positive epistatic gene action (ad) was observed in the first cross; (Rena Mora $\mathrm{x}$ Sakha 1) for no. of branches/plant, no. of pods/plant, no. of seeds/plant and chocolate spot reaction. The same trend was found with respect to dominance $\mathrm{x}$ dominance $(\mathrm{dd})$. While positive or negative significant, were observed for the remaining of the studied characters in these crosses. Generally, at least one of the three types of epistatic gene effects were significant in each crosses for all the studied traits. It could be observed that the significant (aa) type of gene effects appeared to be contributed more to the performance of yield and its components than do the significant (ad) and (dd) gene effects. However, the (aa) gene effects were relatively more important than the (a) effects, but-generally-less important than the (d) effects, moreover, the (aa) gene effects are mostly positive, indicating an enhancing effects on performance of the traits (s) in question, while the (dd) gene effects are negative in most cases giving a diminishing effects which apparently are undesirable form of epistasis. These result were in agreement with those reported by Helal (1997), El-Refaey, 1999; El-Hifny et al. (2001), Kalia and Sood (2004), El-Hady et al. (2006) and EL-Galaly et al. (2008). Heritability values are important to the breeder since it quantifies the expected improvement upon selection. To achieve genetic improvement through selection, heritability must be reasonably high. In the present investigation, the data in Table (5) showed high values of heritability in broad sense ranged from $30.97 \%$ to $95.48 \%$ for no. branches/plant in cross (Sakha $2 \times$ T.W.) and cross (Rena Mora $\times$ Sakha1) for maturity date, respectively. It could be observed that heritability values in the broad-sense were generally higher than the corresponding values in narrow-sense in all crosses for all studied traits, moreover, the crosses differed from one to anather in their estimated values of heritability in broad and narrow-sense. However, high heritability values in broad sense were detected in all crosses for maturity date, no. of pods/plant and seed yield/plant. Moderate estimates of broad sense heritability were observed in all crosses for 100 seed weight and chocolate spot reaction, while relatively low estimates were recorded for no. of branches/plant, where the lowest value was detected in the cross;(Sakha2 $x$ T.W.). The additive genes seems to play an important role of the inheritance of maturity date, no. of branches/plant, no. of pods/plant and chocolate spot reaction in the cross; (Rena Mora x Sakha 1) where the differences between broad and narrow-sense heritability were closest. Narrow-sense heritability estimates were relatively high in the cross (Rena Mora x Sakha1) for maturity date, crosses (Rena Mora x Sakha1) and (Giza 3 
$x$ RenaMora) for no. of pods/plant, cross (Rena Mora $x$ Sakha1) for no. of seeds/plant and cross (Sakha $2 \times$ T.W.) for seed yield/plant, while the lowest of values $\left(h_{n}\right)$ were observed in the cross (Sakha $2 \times$ T.W.) for no. of branches/plant, in the crosses (Giza $3 \times$ RenaMora) and (Sakha $2 \times$ T.W.) for no. of seeds/plant and the crosses (Rena Mora $x$ Sakha1) and (Giza $3 \times$ RenaMora) for 100-seed weight. Johanson et al. (1955) reported that heritability estimated along with genetic gain are usually more useful in predicting the resultant effect of selection than heritability values alone. From this point of view, the progeny of the cross (Rena Mora $\times$ Sakha 1) for maturity date and no. of seeds/plant, the progeny of cross (Giza $3 \times$ RenaMora) for no. of pods/plant and in the progeny of cross (Sakha $2 \times$ T.W.) for seed yield/plant. However, the indirection selection in the progeny of the crosses (Rena Mora $\times$ Sakha 1) and (Sakha $2 \times$ T.W.) and direct selection in the progeny of the cross (Sakha $2 \times$ T.W.) would be fruitful due to the high values of narrow-sense heritability and the predicted genetic advance in these cases. These results are in agreement with those reported by El-Hady et al. (1997), Kalia and Sood (2004), Attia et al. (2006) Al-Ghamdi (2007). and El-Galaly et al.(2008).

Proteins fractionation:

This study was conducted to study the genetic variations among two crosses and three parental genotypes by using SDS-PAGE electrophoresis for total seed proteins Fig. 2. The data in Table 6 showed that the maximum number of 33 bands and the lowest number of bands (30 bands) was found in the Giza 3 and the rest of genotypes had 31 bands. Bands number 16 and 23 with MWs $83,58.30$ and $63 \mathrm{KDa}$, respectively, were absent in Giza 3 and Giza 3 x Rena Mora, so it could be considered as common bands the other genotypes. On the other hand, band no. 16 was present in R.M. and absent in Giza3 but the combination between both hah not this band. Thus, this finding might due to the switch off genes of this band of protein.

Figure 2: Electrophoretic patterns of SDS-PAGE for total soluble protein of five Vicia faba genotypes. 


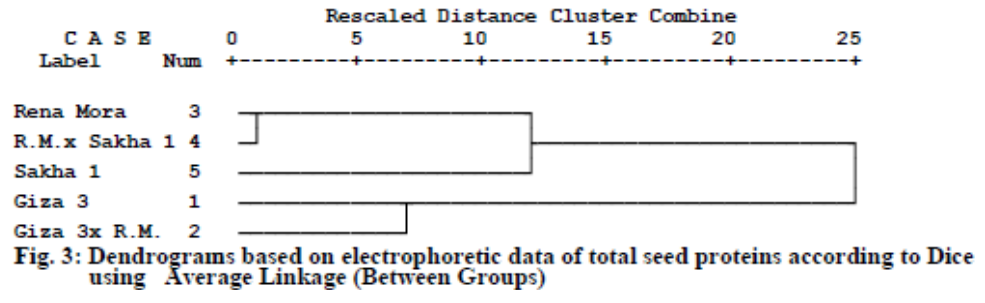

Table(6): Analysis of protein banding patterns by SDS-PAGE for total soluble protein of five Vicia faba genotypes.

\begin{tabular}{|c|c|c|c|c|c|c|}
\hline \multirow[t]{2}{*}{ Band No. } & \multirow[b]{2}{*}{ MW } & \multicolumn{5}{|c|}{ Genotypes } \\
\hline & & Giza 3 & $\begin{array}{c}\text { Giza } 3 x \\
\text { R.M. }\end{array}$ & Rena Mora & R.M. x Sakha 1 & Sakha 1 \\
\hline 1 & 272 & 1 & 1 & 1 & 1 & 1 \\
\hline 2 & 192 & 1 & 1 & 0 & 0 & 0 \\
\hline 3 & 187 & 1 & 1 & 1 & 1 & 1 \\
\hline 4 & 170 & 0 & 1 & 1 & 1 & 0 \\
\hline 5 & 135 & 1 & 1 & 1 & 1 & 1 \\
\hline 6 & 117 & 1 & 1 & 1 & 1 & 1 \\
\hline 7 & 112 & 1 & 1 & 1 & 1 & 1 \\
\hline 8 & 103 & 1 & 1 & 1 & 1 & 1 \\
\hline 9 & 98 & 1 & 1 & 1 & 1 & 1 \\
\hline 10 & 92 & 1 & 1 & 1 & 1 & 1 \\
\hline 11 & 90 & 1 & 1 & 1 & 1 & 1 \\
\hline 12 & 87 & 1 & 1 & 1 & 1 & 1 \\
\hline 13 & 86 & 1 & 1 & 1 & 1 & 1 \\
\hline 14 & 85 & 1 & 1 & 1 & 1 & 1 \\
\hline 15 & 84 & 1 & 1 & 1 & 1 & 1 \\
\hline 16 & 83 & 0 & 0 & 1 & 1 & 1 \\
\hline 17 & 80 & 1 & 1 & 0 & 0 & 1 \\
\hline 18 & 78 & 1 & 1 & 1 & 1 & 1 \\
\hline 19 & 75 & 1 & 1 & 1 & 1 & 1 \\
\hline 20 & 73 & 1 & 1 & 1 & 1 & 1 \\
\hline 21 & 69 & 1 & 1 & 1 & 1 & 1 \\
\hline 22 & 65 & 1 & 1 & 1 & 1 & 1 \\
\hline 23 & 63 & 0 & 0 & 1 & 1 & 1 \\
\hline 24 & 59 & 1 & 1 & 1 & 1 & 1 \\
\hline 25 & 55 & 1 & 1 & 1 & 1 & 1 \\
\hline 26 & 54 & 1 & 1 & 1 & 1 & 1 \\
\hline 27 & 51 & 1 & 1 & 1 & 1 & 1 \\
\hline 28 & 50 & 1 & 1 & 1 & 1 & 1 \\
\hline 29 & 49 & 1 & 1 & 1 & 1 & 1 \\
\hline 30 & 48 & 1 & 1 & 1 & 1 & 1 \\
\hline 31 & 47 & 1 & 1 & 1 & 1 & 1 \\
\hline 32 & 46 & 1 & 1 & 1 & 1 & 1 \\
\hline 33 & 45 & 1 & 1 & 1 & 1 & 1 \\
\hline Total & 33 & 30 & 31 & 31 & 31 & 31 \\
\hline
\end{tabular}

Bands number 2, with MWs 192KDa., was found only in cross Giza 3 x Rena Mora and also exist in the parental genotypes Giza 3 and could be considered as specific bands (positive markers) for these cross. And the data in Table 6 reflect the same direction in the seed protein banding patterns especially for band no 2. The data of SDS-PAGE were loaded to the 
computer program (SPSS windows version 10) to get a dendrogram for genetic distance and similarity matrix as shown in Table 6 and Figure 3 . The dendrogram classified the five genotypes into two groups. The first group included three genotypes were Rena Mora, Rena Mora x Sakha 1 and Sakha 1. While the other group included Giza 3 and Giza 3 x Rena Mora.

Also, in spite of the narrow variation in the number of bands in all genotypes, the Nei's similarity coefficient (Table 7) among all the studied genotypes was small ( 0.918 to 1.0 ), indicating a narrow genetic variation between five genotypes for seed proteins. This genetic variation may be indicated in the polymorphism exhibited in the minor bands and in the major bands intensities. These findings are similar with those reported by Sammour (1992), Abd El-Halim, (1994) Zeicl (2003) and Sammour, (2005). Total protein analysis on the importance of heterosis and its usefulness in the improvement of Vicia faba (Abd EL-Maksoud et al. 2007). These results support the validity of seed protein electrophoresis as a powerful tool for cultivar identification, clarifying taxonomic and evolutionary problems and studying genetic diversity of Vicia faba (Ladizinsky and Hymowitz, 1979; Cooke, 1984; Sammour, 1990a; Signor et al., 2005; Mustafa et al., 2006; Thanh et al., 2006, El-Rodeny, 2006, Abd El-Zaher and Sammour et al., 2007).

Table 7: Genetic similarity index (Dice measure) among faba bean genotypes based on total seed proteins electrophoretic.

\begin{tabular}{|l|c|c|c|c|c|}
\hline Genotypes & Giza 3 & $\begin{array}{c}\text { Giza 3 x } \\
\text { R.M. }\end{array}$ & Rean Mora & $\begin{array}{c}\text { R.M. x Sakha } \\
1\end{array}$ & Sakha 1 \\
\hline Giza 3 & & & & & \\
\hline Giza 3 x R.M. & 0.984 & & & & \\
\hline Rean Mora & 0.918 & 0.935 & & & \\
\hline R.M. x Sakha 1 & 0.918 & 0.935 & 1.000 & & \\
\hline Sakha 1 & 0.951 & 0.935 & 0.968 & 0.968 & \\
\hline
\end{tabular}

\section{REFERENCES}

Abdallah, M.M.F (1977). Performance of $F_{1}$ and $F_{2}$ hybrids of Vicia faba $L$. Egypt. J. Genet. Cytol. 6: 108-121.

Abd El-Halim, R. E. (1994). Quantitative Genetic Studies In Vicia faba L. M.Sc. Thesis, Fac. Agric, Cairo University, Egypt.

Abd EL-Maksoud M.M, M.S. Hamada, M.I Amer, and W.M. El-Rodeny (2007). Biochemical markers for prediction of Vicia faba tolerance to Orobanche. Model legumes congress, 24-28 March 2007, Tunis, Tunisia, P.75.

Abd El-Zaher M.A. Mustafa (2007). Genetic variation among Egyptian cultivars of Vicia faba L. Pakistan Journal of Biological Sciences 10 (23): 4204-4210.

Al-Ghamdi, S.S. (2007). Genetic behavior of some selected faba bean genotypes. $8^{\text {th }}$ African Crop Science Society Conference, El-Minia, Egypt. 
Anderson, R.I. and T.A. Bancroft. (1952). Statistical theory in Research. McGraw-Hill Company, N.Y., U.S.A.

Attia, Sabah M.; M.M. El-Hady, E.M. Rabie and Ola, A.M. ElGalaly(2006). Genetical analysis of yield and its components using six populations model in faba bean (Vicia faba L.).

Bernier,C.C; S.B. Hanounik; M.M. Hussein and H.A. Mohamed (1984). Field manual of common faba bean diseases in the Nile Valley. information Bulletin. International Center for Agric.Res. in the Dry Areas (ICARDA).No.3.

Bond, D.A., G.J. Jellis, G.G. Rowland, J. Le Guen, L.D. Robertson, S.A. halil, and L. Li Juan. (1994). Present status and future strategy in breeding faba beans (Vicia faba L.) for resistance to biotic and abiotic stresses. Euphytica 73:151-166.

Cooke, R.J., (1984). The characterization and identification of crop cultivars by electrophoresis. Electrophoresis, 5: 59-72.

Ebmeyer, E., and D. Stelling. (1994). Genetic structure of three open pollinated faba bean varieties, Vicia faba L. Plant Breeding 112:17-23.

EL-Galaly, Ola .A.M.; R.A.I. Abo Mostafa, and W.M. EL- Rodeny (2008), Evaluation of eight promising lines of faba bean (Vicia faba L.) for diseases resistance (chocolate spot and rust) and yield in north delta . Annals of Agric . Sc., Moshtohor, Vol. 46(2): Ag. 131-140, (2008).

El-Hady, M.M.; Gh.A. Gad El-Karim and M.A. Omar (1997). Genetical studies in faba bean (Vicia faba L.). J. Agric. Sci. Mansoura Univ. 22: 3561-3571.

El-Hady, M.M.; M.A. Omar; S.M. Naser; K.A. Ali and M.S. Essa (1998). Gene action on seed yield and of some yield components in $F_{1}$ and $F_{2}$ crosses among five faba bean (Vicia faba L.) genotypes. Bull. Fac. Agric., Cairo University, 49: 369-388.

EL-Hady, M.M.; Sabah M. Attia; Ola A.M.EL. Galaly and Manal M.Salem, (2006) . Heterosis and combining ability analysis of some faba bean genotypes .J. Agric. Res. Tanta Univ., 32 (1) 134-148 (2006).

El-Hifny, M.Z.; M.M. Eissa; B.R. Bakheit and S.B. Ragheb (2001). Inheritance of some agronomic characters method in five faba bean (Vicia faba $L$.) crosses using six population.

The Second PI. Breed. Conf.,October 2, 2001 (Assiut University).345360.

El-Hosary, A.A.; S. Shokr; A.A.A. El-Halim; S.M. Nasr and A.M.A. Aziz (1997). Heterosis and combining ability in faba bean (Vicia faba L.). Egyptian Journal of Agricultural Research. 1997, 75:3, 811-826.

El-Refaey, R.A. and M.M.Radi (1991) Genetic analysis of seed yield and its related character in soybean. II- Inbreeding depression and interrelationships among traits in the F1 and F2 generations. J.Agric. Res.Tanta Univ., 17(2):334-345.

El-Refaey, R.A. (1999). Generation mean analysis of earliness, yield and some of its components in three faba bean crosses. Minufiya J. Agric. Res. 24: 409-424. 
El-Rodeny, W.M. (2006). Genetically studies on some Vicia faba cultivars. Ph.D. Thesis, Genetics Dep., Faculty of Agriculture, Mansoura University, Egypt

Gamble,E.E., (1962).Gene effects in corn (Zea mays L.). I- Separation and relative importance of gene effects for yield.Can. J.of Plant Sci., 42: 339-348.

Gatehouse, J. A.; R. D. Croy; R. McIntoch; C. Paul and D. Boulter. (1980). Quantitative and qualitative variation in the storage proteins from the EEC joint field bean. In (Vicia faba L. Feeding Value, Processing and Viruses (Bond, D.A., Ed) pp. 173-190. ECSC, EEC, EAEC, Brussels.

Gates, P. and D. Boulter. (1979). The use of seed isoenzymes as an aid to the breeding of field bean (Vicia faba L.) New Phytologist. 83 (3): 783790.

Hayman, B.I. and K. K. Mather (1955). The description of genetic interaction in continuous variation. Biometrics, 11: 69-82.

Helal, A. G. (1997). Studies on breeding of some genotypes in faba bean (Vicia faba L.) M.Sc. Thesis Fac. Agric., Al-Azhar Univ., Egypt.

Hendawy,F.A (1994). Heterosis and inheritance of some quantitative characters in two intervarietal crosses of field bean (Vicia faba L.) Minufiya J.Agric .Res.19:1957-1971

Johnson, H.W. , H.F. Robinson, and R.E. Comstock,(1955). Estimating of genetic and environmental variability in soybeans. Agron. J., 47: 314318.

Kalia, P. and S. Sood (2004). Genetic variation and association analyses for pod yield and other agronomic and quality characters in an Indian himalayan collection of broad bean (Vicia Faba L.) . sabrao journal of breeding and genetics 36(2) 55-61.

Khalil,S.A.; M.M.El-Hady; R.F. Dissouky; M.I.Amer and S.A. Omer (1993-b). Breeding for high yielding ability with improved level of resistance to chocolate spot ( Botrytis faba ) diseases in faba bean (Vicia faba L.). J Agric. Sci . Mansoura Univ. 18(5) : 1315-1328.

Kour, A and S.P. Singh, (2004). Evaluation of genetic diversity in different genotypes of Brassica juncea by SDS-PAGE. New directions for a diverse planet: Proceedings of the 4th International Crop Science Congress, Brisbane, Australia, 26 Sep-1 Oct.

Ladizinsky, G. and T. Hymowitz, (1979). Seed protein electrophoresis in taxonomic and evolutionary studies. Theor. Applied Genet., 54: 145-15l.

Laemmli, U.K., 1970. Cleavage of structural proteins during the assembly of the head of bacteriophage T 4. Nature, 227: 680-685.

Mather, K. and J.L. Jinks (1971). Biometrical Genetics. ${ }^{\text {nd }}$ ed. Chapman and Hall Ltd., London,pp.382.

Mather,K. (1949). Biometrical Genetics. Dover Publications, Inc., London

Miller, P.A., J.C. Williams, H.F. Robinson and R.E. Comstock (1958). Estimates of genotypic and environmental variances and covariance in upland cotton and their implications in selection.Agron.J., 50: 126-131. 
Mohamed, H.A.; M.E. El-Rafei; N.M. Abou Zeid; S.A. Omer; Wadaia F. Habib.; I.A. Ismail, ; M. Raof.; and H. Khidr; (1980). Plant pathobgy research studies ICARDA/IFAD Nile Valley Project on faba beans Annual coordination Meeting 1979-1980, Cairo, Mimeograph, 49pp.

Mustafa, A.M.A., A Baclr, MA El-Galaly, AA Mobarak and M.G. Hassan, (2006). Genetic diversity among Ocimum populations in Egypt as reflected by morphological, seed proteins and Isozyme polymorphism. Int. J. Bot., 2: 261-269.

Nei, M. and W. Li, (1979). Mathematical model for studying genetic variation in terms of restriction endonucleases. Proc. Nat. Acad. Sci., USA, 76: 5256-5273.

Sammour, R, A. Mustafa, S. Badr and W. Taher, (2007). Genetic variations in accessions of Lathyrus sativus L. Acta Bot. Croat., 66: 1-13.

Sammour, RH., 1988. Flax seed proteins: Comparison by various PAGEtechniques in slabs. Agron. Crop Sci., 160: 271.

Sammour, RH, (1992). An electrophoretic analysis of the variation in the seed storage proteins of Vicia faba L. cultivars. Feddes Repertorium, 103: 555-557.

Sammour, RH, (2005). Molecular reassessment of relationships within Vicieae using electrophoretic and immunochemical techniques. Afr. Crop Sci. J., 13: 27-39.

Sammour, RH., (1990a). Seed protein electrophoresis of Vicia faba L. and their immediate progenitors, a-reappraisal. Plant Breed., 101: 176.

Signor, C.L., K. Gallardo, J.M. Prosperi, C. Salon, L. Quillien, R Thompson and G. Duc, 2005. Genetic diversity for seed protein composition in Medicago truncatula. Plant Genet. Resour., 3: 59-71.

Smith, H.H. (1952). Fixing transgressive vigor in Nicotiana rustica. In heterosis, lowa State Collage Press. Ames, lowa, U. S. A.

Stegemann, H, 1983. Discrimination among Intraspecific Taxa Using Electrophoretic Data. In: Proteins and Nucleic Acids in Plant Systemic, Jensen, U. and D.E. Fairbrothers (Eds.). Berlin. Springer-Verlag, pp: 124-128.

Thanh, V.c., P.V. Phuong, P.H.H. Uyen and P.P. Hien, (2006). Application of protein electrophoresis SDSPAGE to evaluate genetic purity and diversity of several varieties. Proceedings of International Workshop on Biotechnology in Agriculture; Nong Lam University Ho Chi Minh City, October 20-21, pp: 192-194.

Toker, C. (2004). Estimates of broad -sense heritability for seed yield and yield criteria in faba bean (Vicia faba L.) Heredities 140,222-225.

Zeicl, M.M., (2003). Analysis of genetic diversity based on molecular markers (AFLP) and of heterosis in faba bean (Vicia faba L.). Doctoral Dissertation in Fac. Agric. Sci., Georg-August-Uni. Goettingen, Germany. 


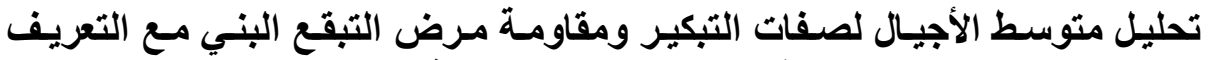

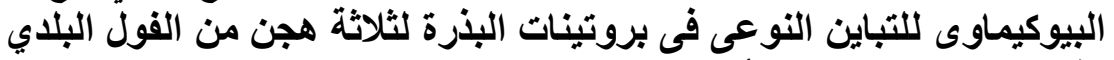

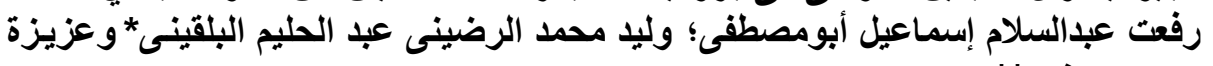

** محمد حسنين عزئ

* مركز البحوث الزيراعية ـ معهد بحوث المحاصيل الحقلية ـ قسم بحوث المحاصبيل البقولية.

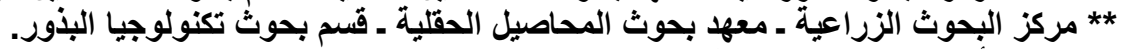

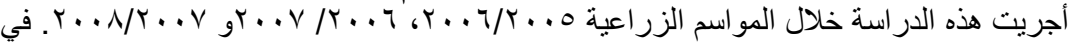

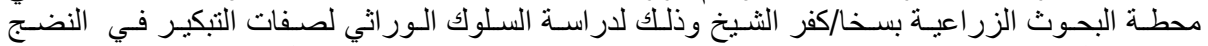

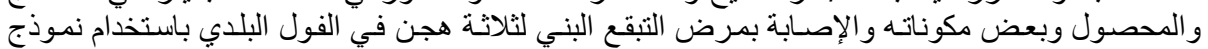

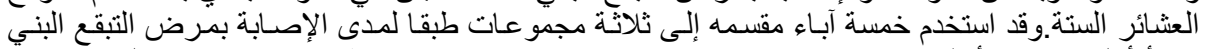

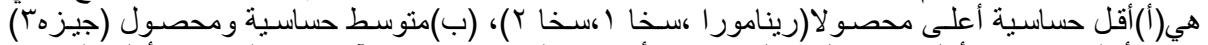

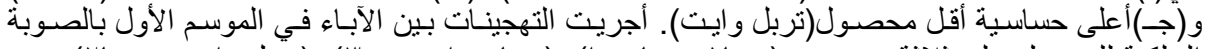

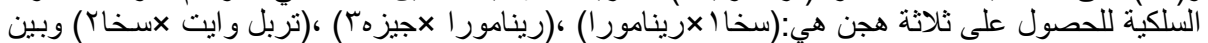

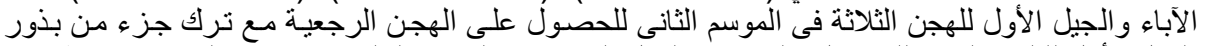

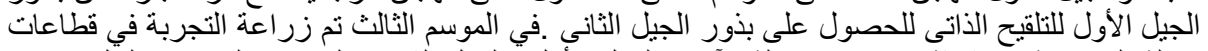

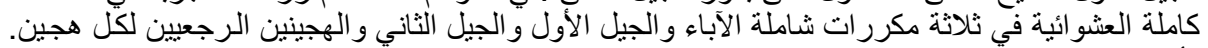
و أظهرت النتائج الآتي:-

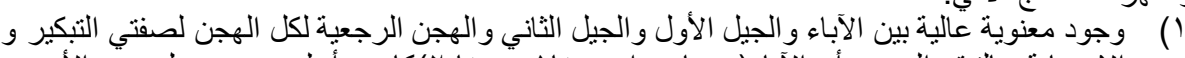

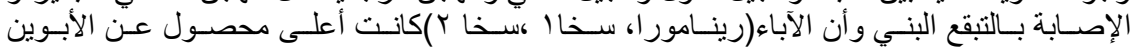

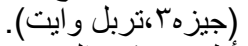

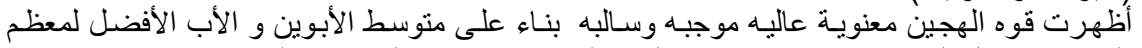

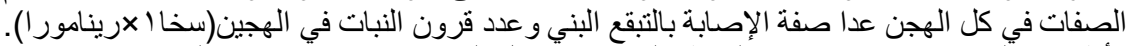

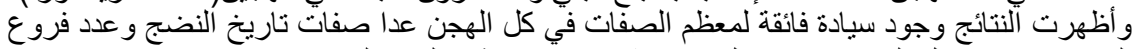

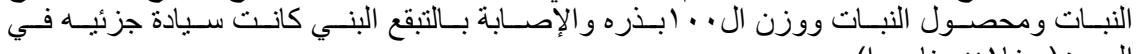

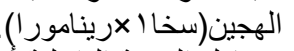

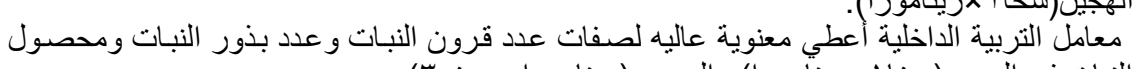

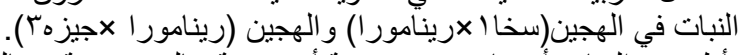

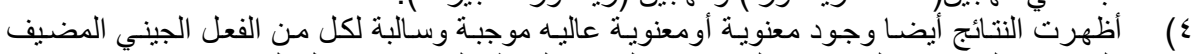

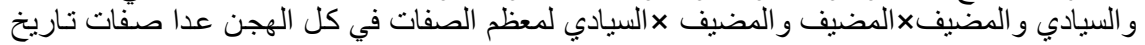

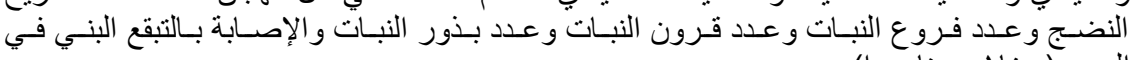
الهجين(سخا ×ارينامورا).

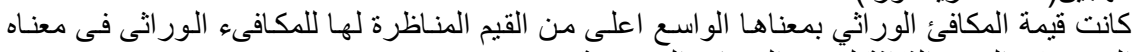

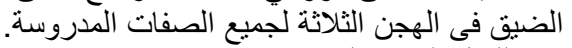

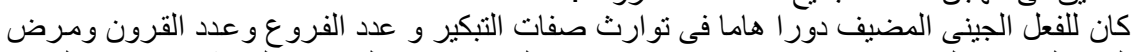

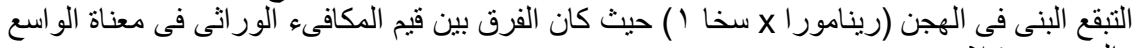
و الضيق ضئيلا.

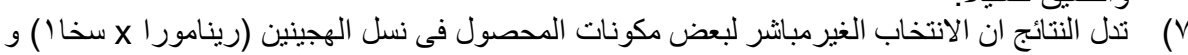

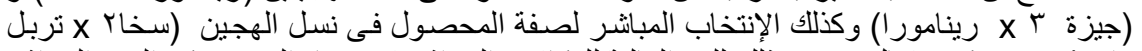
وايت) سوف يكون فعال ويرجع ذللك للقيم العالية للمكافىء الور اثى فى معناه الضيق وقيم التقام الور اثىى

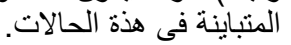

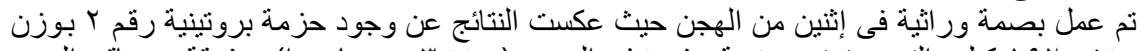

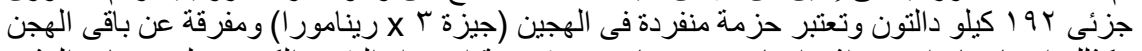

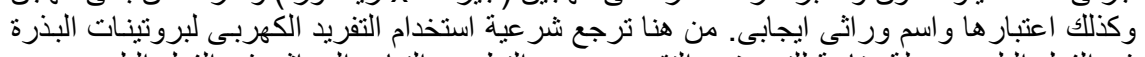

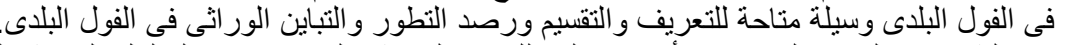

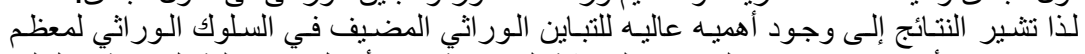

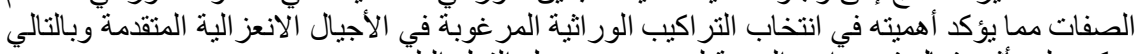
سيكون له نأثير فعال في برامج التربية لتحسين محصول الفول البلائي. 
Abo Mostafa, R.A.l. et al. 
Table 4: Heterosis over mid Parent (M.P) and better parent (B.P), inbreeding depression(I.D.\%) and potence ratio for all studies traits in three faba bean crosses.

\begin{tabular}{|c|c|c|c|c|c|}
\hline \multirow[b]{2}{*}{ Traits } & \multirow[b]{2}{*}{ Cross } & \multicolumn{2}{|c|}{ Heterosis } & \multirow{2}{*}{$\begin{array}{c}\text { Inbreeding Depression } \\
(\mathrm{I} . \mathrm{D} \%)\end{array}$} & \multirow[b]{2}{*}{ Potence ratio $(P)$} \\
\hline & & M.P & B.P & & \\
\hline \multirow[b]{3}{*}{ Maturity date } & Rena Mora x Sakha1 & $-6.89^{* *}$ & $-4.86^{* *}$ & $-7.63^{*}$ & -3.22 \\
\hline & Giza 3 x Rena Mora & $4.01^{* *}$ & $6.63^{* *}$ & 3.22 & 1.64 \\
\hline & Sakha $2 \times$ T.W. & $2.19^{\star \star}$ & $9.58^{* *}$ & -1.92 & 0.33 \\
\hline \multirow{3}{*}{$\begin{array}{l}\text { Chocolate } \\
\text { reaction }\end{array}$} & Rena Mora $\times$ Sakha1 & -6.67 & -4.21 & -16.89 & -2.60 \\
\hline & Giza 3 x Rena Mora & $-32.62^{*}$ & -17.39 & -12.64 & -1.77 \\
\hline & Sakha $2 \times$ T.W. & -2.96 & $45.56^{* *}$ & 0.96 & -0.09 \\
\hline \multirow{3}{*}{$\begin{array}{l}\text { No. of branches } \\
\text { plant }\end{array}$} & Rena Mora x Sakha1 & $58.75^{* *}$ & $28.30^{* *}$ & $32.68^{\star *}$ & 2.48 \\
\hline & Giza 3 x Rena Mora & $36.65^{* *}$ & 14.58 & $35.80^{*}$ & 1.90 \\
\hline & Sakha $2 \times$ T.W. & $40.09^{* *}$ & $-18.28^{\star \star}$ & $47.93^{* \star}$ & 0.56 \\
\hline \multirow[b]{3}{*}{ No. of pods/ plant } & Rena Mora x Sakha1 & $41.60^{* *}$ & 2.18 & $61.10^{\star \star}$ & 1.08 \\
\hline & Giza 3 x Rena Mora & $33.66^{* *}$ & $-1.82^{* *}$ & $34.44^{\star \star}$ & 0.93 \\
\hline & Sakha $2 \times$ T.W. & $25.36^{* *}$ & $9.30^{*}$ & 11.04 & 1.73 \\
\hline \multirow{3}{*}{$\begin{array}{l}\text { No. of seeds/ } \\
\text { plant }\end{array}$} & Rena Mora x Sakha1 & $39.70^{* *}$ & $21.56^{* *}$ & $35.15^{\star \star}$ & 2.66 \\
\hline & Giza 3 x Rena Mora & $31.78^{* *}$ & $2.31^{* *}$ & $56.84^{* *}$ & 1.10 \\
\hline & Sakha $2 \times$ T.W. & $12.86^{* *}$ & $5.99^{\star \star}$ & $4.94^{\star}$ & 1.98 \\
\hline \multirow{3}{*}{$\begin{array}{l}\text { Seed yield/ } \\
(\mathrm{gm})\end{array}$} & Rena Mora x Sakha1 & $63.90^{* *}$ & $53.63^{* *}$ & $27.80^{\star *}$ & 9.57 \\
\hline & Giza 3 x Rena Mora & $32.21^{* *}$ & $17.78^{* *}$ & $48.74^{\star \star}$ & 2.63 \\
\hline & Sakha $2 \times$ T.W. & $6.86^{* *}$ & $-5.65^{\star *}$ & 4.20 & 0.52 \\
\hline \multirow{3}{*}{$\begin{array}{l}\text { 100-seed } \\
(\mathrm{gm})\end{array}$} & Rena Mora x Sakha1 & $13.52^{* *}$ & $-6.49^{* *}$ & -3.27 & 0.63 \\
\hline & Giza 3 x Rena Mora & $3.17^{*}$ & $-12.87^{\star \star}$ & -2.81 & 0.17 \\
\hline & Sakha $2 \times$ T.W. & 3.23 & $-10.90^{\star \star}$ & -0.59 & 0.20 \\
\hline
\end{tabular}


Table 5: Mother's scaling test for average addictiveness, Gamble's parameters for determining gene action, broad $(H)$ and narrow heritability $\left(h^{2} n\right)$, Genetic advance (Gs \%) as percentage of $F_{2}$ means and phenotypic variance components for three faba bean crosses for all studied traits.

\begin{tabular}{|c|c|c|c|c|c|c|c|c|c|c|c|c|}
\hline \multirow{2}{*}{\begin{tabular}{|l|} 
Traits \\
Genotypes \\
\end{tabular}} & \multicolumn{3}{|c|}{ Maturity date } & \multicolumn{3}{|c|}{ Chocolate spot Reaction } & \multicolumn{3}{|c|}{ No. of branches/plant } & \multicolumn{3}{|c|}{ No. of pods/plant } \\
\hline & & II & III & & & III & 1 & & III & 1 & & III \\
\hline \multicolumn{13}{|c|}{ I-Scaling test: } \\
\hline A & $16.03^{* *}$ & -1.92 & $4.27^{* *}$ & 0.33 & $0.85^{\star *}$ & $-3.17^{* *}$ & $3.08^{* *}$ & $-7.03^{* *}$ & $3.70^{* *}$ & $5.63^{\star *}$ & $-7.70^{* *}$ & $9.52^{* *}$ \\
\hline B & $20.47^{* *}$ & -0.58 & $21.88^{* *}$ & 0.18 & $-2.73^{\star *}$ & $1.53^{* \star}$ & $-1.35^{\star \star}$ & $-1.47^{* *}$ & $-0.97^{\star \star}$ & $-5.12^{* \star}$ & $-2.73^{\star \star}$ & $5.27^{* \star}$ \\
\hline $\mathbf{C}$ & $25.10^{* *}$ & $-7.60^{* *}$ & $18.00^{* *}$ & $2.21^{* *}$ & $-1.23^{*}$ & -0.43 & $-1.67^{*}$ & $-3.80^{* *}$ & $-3.67^{* *}$ & $-33.43^{*}$ & $-16.83^{* *}$ & 0.23 \\
\hline D & $-5.70^{\star \star}$ & -2.55 & $-4.07^{\star \star}$ & $0.85^{\star \star}$ & 0.33 & 0.60 & $-1.70^{\star \star}$ & $2.35^{\star \star}$ & $-3.20^{\star \star}$ & $-16.98^{\star *}$ & $-3.20^{\star \star}$ & $-7.28^{\star \star}$ \\
\hline \multicolumn{13}{|c|}{ II- Gene Effect: } \\
\hline $\mathbf{M}$ & $149.18^{* *}$ & $154.85^{* *}$ & $151.18^{* *}$ & $3.65^{* *}$ & $3.63^{* *}$ & $4.33^{* *}$ & $5.13^{* *}$ & $5.40^{* *}$ & $3.43^{* *}$ & $22.33^{* *}$ & $24.03^{* *}$ & $30.35^{\star *}$ \\
\hline Additive & 0.95 & $3.10^{* *}$ & $0.97^{*}$ & $0.05^{*}$ & $0.03^{* \star}$ & $-0.85^{* *}$ & $\frac{0.15}{1.20^{* *}}$ & $\frac{0.40}{-1.75^{* *}}$ & $\frac{0.40}{-0.25^{*}}$ & $-4.43^{* *}$ & $\frac{64.05}{6.25^{* *}}$ & $\frac{0.00}{-1.83^{* *}}$ \\
\hline Dominance (d) & 1.20 & $11.27^{* *}$ & $11.33^{* *}$ & $-1.83^{\star \star}$ & $-2.18^{* *}$ & -1.33 & $5.92^{* *}$ & $-2.73^{* *}$ & $7.85^{* *}$ & $44.52^{* *}$ & $14.53^{* *}$ & $21.37^{* *}$ \\
\hline (aa) & $11.40^{* *}$ & $5.10^{\star \star}$ & $8.15^{\star \star}$ & $-1.70^{\star \star}$ & -0.65 & $-1.20^{\star \star \star}$ & 3.40 & $-4.70^{* *}$ & $6.40^{* *}$ & $33.95^{* *}$ & $6.40^{* *}$ & $14.55^{\star \star}$ \\
\hline (ad) & $-2.22^{\star}$ & -0.67 & $-8.81^{\star \star}$ & $0.42^{* *}$ & 0.06 & $0.65^{\star *}$ & $0.18^{* *}$ & $-0.72^{\star *}$ & $-2.83^{* *}$ & $5.38^{* *}$ & $\frac{0.74}{-2.48}$ & $2.13^{* *}$ \\
\hline (dd) & $-47.90^{* \star}$ & $-2.60^{\star \star}$ & -34.30 & 1.19 & $2.53^{\star \star}$ & $2.83^{\star \star}$ & $-5.13^{\star \star}$ & 13.20 & -9.13 & $-34.47^{* *}$ & 4.03 & -29.33 \\
\hline \multicolumn{13}{|c|}{ IIl- Phenotypic Variance Components: } \\
\hline Additive variance(D) & 50.44 & 20.19 & 4.06 & 0.38 & 0.92 & 0.62 & 0.90 & 0.74 & 0.04 & 8.87 & 17.66 & 6.25 \\
\hline Dominance varianc & 8.97 & 21.49 & 5.75 & 0.07 & 0.17 & 0.76 & 0.06 & 0.17 & 0.29 & 1.23 & 1.50 & 1.67 \\
\hline Environmental variance (E) & 1.29 & 0.71 & 0.72 & 0.23 & 0.25 & 0.24 & 0.51 & 0.39 & 0.21 & 0.81 & 0.50 & 1.14 \\
\hline Ratio of dominance & & & & & & & & & & & & \\
\hline $\begin{array}{l}\text { variance } \\
\mathrm{H}\end{array}$ & $\begin{array}{c}0.42 \\
95.48\end{array}$ & $\begin{array}{c}1.03 \\
95.58\end{array}$ & $\begin{array}{r}1.19 \\
8258\end{array}$ & $\begin{array}{c}0.44 \\
48.09\end{array}$ & $\begin{array}{c}0.43 \\
6688\end{array}$ & $\begin{array}{r}1.11 \\
6754\end{array}$ & $\begin{array}{c}0.26 \\
47.47\end{array}$ & $\begin{array}{c}0.47 \\
51.01\end{array}$ & $\begin{array}{c}2.57 \\
30.97\end{array}$ & $\begin{array}{l}0.37 \\
8532\end{array}$ & $\begin{array}{c}0.29 \\
9475\end{array}$ & 0.52 \\
\hline Hn & 87.69 & $\begin{array}{l}5.50 \\
62.38\end{array}$ & $\frac{0.50}{48.34}$ & $\begin{array}{l}40.09 \\
43.86\end{array}$ & 60.00 & 41.88 & 45.86 & $\begin{array}{l}51.01 \\
5.89\end{array}$ & $\frac{7.91}{7.22}$ & $\begin{array}{l}8.02 \\
79.79\end{array}$ & 94.15 & $\begin{array}{l}15.44 \\
66.53\end{array}$ \\
\hline Gs\% & 9.69 & 5.17 & $\frac{70.04}{2.04}$ & 0.60 & 1.09 & 0.74 & 0.94 & 0.85 & 0.08 & 3.88 & 5.84 & 2.97 \\
\hline Mora & $x$ & a1) & & & & Rena & Mora & & & III & $\begin{array}{l}\text { a.04 } \\
\text { aha2 }\end{array}$ & \\
\hline
\end{tabular}




\section{J. Agric. Sci. Mansoura Univ., 34 (2), February, 2009}

Table 5: Cont.

\begin{tabular}{|c|c|c|c|c|c|c|c|c|c|}
\hline Traits & & f seeds/pl & & & yield/plat & & & eed weigh & \\
\hline Genotypes & $\mathrm{I}$ & II & III & I & II & III & I & II & III \\
\hline & & & & I-Scaling $t e$ & & & & & \\
\hline $\mathbf{A}$ & $37.22^{\star \star}$ & $-43.88^{* *}$ & $3.10^{* *}$ & $46.30^{* *}$ & $-12.34^{* *}$ & $78.54^{* *}$ & $-8.22^{\star *}$ & $11.55^{\star \star}$ & $69.34^{\star *}$ \\
\hline $\mathbf{B}$ & $20.47^{* *}$ & $-34.70^{* *}$ & $16.97^{\star \star}$ & $27.94^{* *}$ & $-44.11^{\star *}$ & $57.42^{* *}$ & $21.47^{* *}$ & $9.48^{* *}$ & $83.82^{* *}$ \\
\hline C & $-49.07^{\star \star}$ & $-112.73^{* *}$ & $3.37^{\star \star}$ & $-10.34^{* *}$ & $-92.77^{* *}$ & -2.20 & $41.10^{\star *}$ & $17.73^{* *}$ & $6.81^{* *}$ \\
\hline D & $-53.38^{\star *}$ & $-17.08^{\star *}$ & $-8.35^{\star \star}$ & $-42.29^{*}$ & $-18.16^{\star *}$ & $-69.08^{\star \star}$ & $13.92^{* *}$ & -1.65 & $-73.17^{* *}$ \\
\hline & & & & II- Gene Ef & & & & & \\
\hline $\mathbf{M}$ & $76.90^{\star \star}$ & $74.3^{\star \star}$ & $81.00^{\star \star}$ & $89.48^{* \star}$ & $75.74^{\star \star}$ & $64.30^{* *}$ & $113.75^{\star \star}$ & $102.98^{\star \star}$ & $79.43^{\star *}$ \\
\hline Additive & $-2.73^{* *}$ & $20.88^{* *}$ & $-2.05^{\star *}$ & $4.52^{\star *}$ & $5.45^{\star *}$ & $2.24^{* *}$ & $5.89^{* *}$ & $-16.82^{* *}$ & $4.89^{* *}$ \\
\hline Dominance (d) & $136.28^{\star *}$ & $62.25^{\star *}$ & $26.38^{\star \star}$ & $129.16^{\star *}$ & $63.76^{\star \star}$ & $142.46^{\star \star}$ & $-14.74^{\star \star}$ & $6.38^{*}$ & $148.81^{\star \star}$ \\
\hline (aa) & $106.75^{\star *}$ & $34.15^{\star *}$ & $16.70^{* *}$ & $84.58^{\star *}$ & $36.32^{\star *}$ & $138.16^{* *}$ & $-27.85^{\star \star}$ & 3.31 & $146.34^{\star *}$ \\
\hline (ad) & $8.37^{* *}$ & $-4.59^{* *}$ & $-6.93^{* \star}$ & -0.14 & $-4.98^{\star *}$ & $-6.08^{* *}$ & $-14.85^{\star \star}$ & 1.03 & $-7.24^{* *}$ \\
\hline (dd) & $-164.43^{* *}$ & $44.43^{* *}$ & $-36.77^{\star *}$ & $-158.82^{* *}$ & $20.13^{* *}$ & $-274.12^{\star *}$ & $14.59^{* *}$ & $-24.34^{\star *}$ & $-299.49^{\star \star}$ \\
\hline & & & III- Phenc & oic Varianc & ompone & & & & \\
\hline Additive variance(D) & 45.97 & 4.06 & 1.97 & 14.26 & 14.37 & 13.56 & 12.02 & 4.74 & 14.14 \\
\hline Dominance variance $(\mathrm{H})$ & 13.22 & 17.19 & 4.36 & 45.28 & 38.86 & 0.08 & 32.88 & 53.05 & 16.69 \\
\hline $\begin{array}{l}\text { Environmental } \\
\text { variance(E) }\end{array}$ & 2.29 & 0.65 & 2.00 & 1.54 & 0.64 & 0.93 & 6.96 & 1.41 & 4.15 \\
\hline $\begin{array}{l}\begin{array}{l}\text { Ratio of dominance } \\
\text { variance }\end{array} \\
\end{array}$ & 0.54 & 2.06 & 1.49 & 1.78 & 1.64 & 0.08 & 1.65 & 3.34 & 1.09 \\
\hline H & 91.90 & 90.60 & 50.64 & 92.24 & 96.34 & 87.81 & 66.92 & 91.67 & 72.86 \\
\hline Hn & 80.34 & 29.08 & 24.06 & 35.65 & 40.96 & 87.54 & 28.27 & 13.91 & 45.81 \\
\hline Gs\% & 8.85 & 1.58 & 1.00 & 3.28 & 3.53 & 5.02 & 2.69 & 1.18 & 3.71 \\
\hline
\end{tabular}

( Rena Mora x Sakha1) II (Giza3 x Rena Mora) III (Sakha2 x T.W.) 
Abo Mostafa, R.A.l. et al.

Table 3: Mean performance $(x)$, mean variance $\left(S^{2} x\right)$ and coefficient of variation (C.V.\%) for the six populations of the crosses for different traits

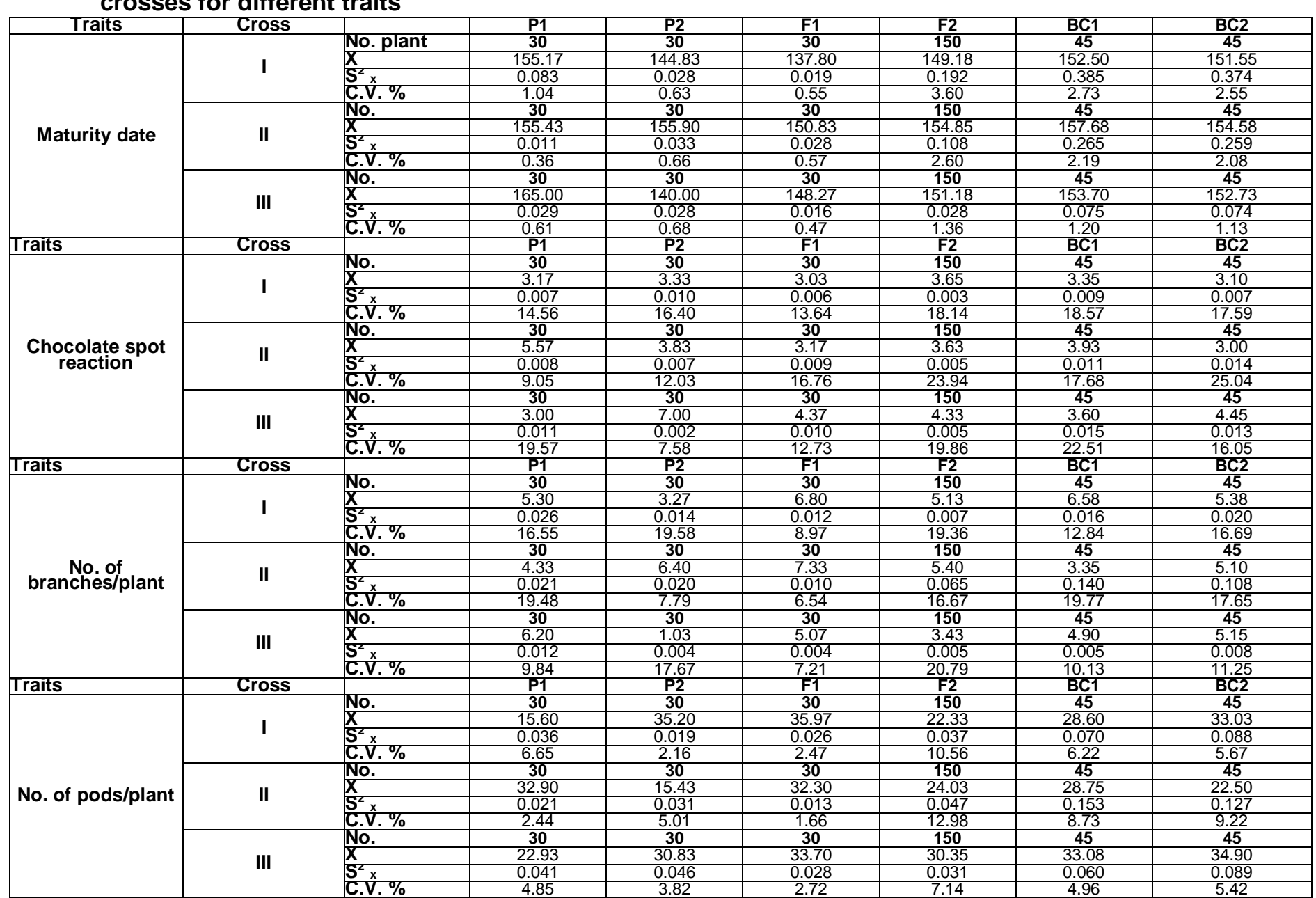

I ( Rena Mora x Sakha1) II (Giza3 x Rena Mora) III (Sakha2 x T.W. 


\section{J. Agric. Sci. Mansoura Univ., 34 (2), February, 2009}

Table 3:cont.

\begin{tabular}{|c|c|c|c|c|c|c|c|c|}
\hline Traits & Cross & & P1 & $\mathbf{P 2}$ & F1 & F2 & BC1 & BC2 \\
\hline \multirow{12}{*}{ No. of seeds/plant } & & No. & 30 & 30 & 30 & 150 & 45 & 45 \\
\hline & \multirow{3}{*}{ I } & $x$ & 63.30 & 85.50 & 103.93 & 76.90 & 102.23 & 104.95 \\
\hline & & $S^{2} x$ & 0.113 & 0.096 & 0.023 & 0.191 & 0.422 & 0.381 \\
\hline & & C.V. \% & 2.91 & 1.98 & 0.80 & 6.95 & 4.26 & 3.72 \\
\hline & \multirow{4}{*}{ II } & No. & 30 & 30 & 30 & 150 & 45 & 45 \\
\hline & & $X$ & 113.90 & 62.97 & 116.53 & 74.30 & 93.28 & 72.40 \\
\hline & & $S^{2} x$ & 0.022 & 0.033 & 0.009 & 0.117 & 0.317 & 0.341 \\
\hline & & C.V. \% & 0.71 & 1.53 & 0.54 & 3.56 & 2.81 & 3.11 \\
\hline & \multirow{4}{*}{ III } & No. & 30 & 30 & 30 & 150 & 45 & 45 \\
\hline & & $\mathrm{X}$ & 80.20 & 70.43 & 85.00 & 81.00 & 84.15 & 86.20 \\
\hline & & $S^{2} x$ & 0.148 & 0.045 & 0.009 & 0.027 & 0.092 & 0.077 \\
\hline & & C.V. \% & 2.63 & 1.65 & 0.62 & 2.50 & 2.42 & 2.04 \\
\hline Traits & Cross & & P1 & P2 & F1 & F2 & BC1 & $\mathrm{BC2}$ \\
\hline \multirow{12}{*}{$\begin{array}{l}\text { Seed yield / } \\
\text { plant(gm) }\end{array}$} & \multirow{4}{*}{ I } & No. & 30 & 30 & 30 & 150 & 45 & 45 \\
\hline & & $\mathbf{X}$ & 74.43 & 65.11 & 114.35 & 89.48 & 112.88 & 108.36 \\
\hline & & $S^{2} x$ & 0.076 & 0.050 & 0.030 & 0.133 & 0.334 & 0.446 \\
\hline & & C.V. $\%$ & 2.02 & 1.88 & 0.83 & 5.00 & 3.43 & 3.90 \\
\hline & \multirow{4}{*}{ II } & No. & 30 & 30 & 30 & 150 & 45 & 45 \\
\hline & & $\mathbf{X}$ & 55.65 & 74.78 & 112.66 & 75.74 & 87.55 & 82.10 \\
\hline & & $S^{2} x$ & 0.022 & 0.033 & 0.009 & 0.117 & 0.317 & 0.341 \\
\hline & & C.V. \% & 1.45 & 1.33 & 0.46 & 5.53 & 4.31 & 4.50 \\
\hline & \multirow{4}{*}{ III } & No. & 30 & 30 & 30 & 150 & 45 & 45 \\
\hline & & $\bar{x}$ & 71.02 & 54.38 & 67.00 & 64.30 & 99.96 & 97.72 \\
\hline & & $S^{2} x$ & 0.058246 & 0.014938 & 0.021202 & 0.051629 & 0.072102 & 0.13661 \\
\hline & & C.V. \% & 1.86 & 1.23 & 1.19 & 4.33 & 1.80 & 2.39 \\
\hline Traits & Cross & & P1 & P2 & F1 & F2 & BC1 & BC2 \\
\hline \multirow{12}{*}{$\begin{array}{c}100 \text {-seed } \\
\text { weight(gm) }\end{array}$} & \multirow{4}{*}{ I } & No. & 30 & 30 & 30 & 150 & 45 & 45 \\
\hline & & $x$ & 117.67 & 76.19 & 110.03 & 113.75 & 109.74 & 103.84 \\
\hline & & $S^{2} x$ & 0.485 & 0.166 & 0.053 & 0.142 & 0.420 & 0.440 \\
\hline & & C.V. \% & 3.24 & 2.93 & 1.14 & 4.05 & 3.96 & 4.04 \\
\hline & \multirow{4}{*}{ II } & No. & 30 & 30 & 30 & 150 & 45 & 45 \\
\hline & & $\mathbf{X}$ & 79.16 & 114.87 & 100.09 & 102.98 & 95.40 & 112.22 \\
\hline & & $S^{2} x$ & 0.044 & 0.061 & 0.038 & 0.114 & 0.331 & 0.422 \\
\hline & & C.V. \% & 1.44 & 1.18 & 1.06 & 4.01 & 4.04 & 3.66 \\
\hline & \multirow{4}{*}{ III } & No. & 30 & 30 & 30 & 150 & 45 & 45 \\
\hline & & $x$ & 88.62 & 64.36 & 78.96 & 79.43 & 118.46 & 113.57 \\
\hline & & $S^{2} x$ & 0.361 & 0.025 & 0.032 & 0.103 & 0.275 & 0.285 \\
\hline & & C.V. \% & 3.71 & 1.35 & 1.25 & 4.95 & 2.97 & 2.97 \\
\hline
\end{tabular}

I ( Rena Mora x Sakha1) II (Giza3 x Rena Mora) III (Sakha2 x T.W.) 